\title{
NOVOS ESTUDOS EM MORFOSSINTAXE: ABORDAGENS E DINÂMICAS QUE VIABILIZEM A PRÁTICA DO PROFESSOR DE LÍNGUA PORTUGUESA
}

É com grande prazer que apresentamos à comunidade acadêmica este oitavo número da Pensares em Revista, o qual contém 7 (sete) artigos científicos, uma resenha e uma entrevista. É mister ressaltar que, em conformidade com a orientação do dossiê, os textos selecionados apresentam uma abordagem voltada para o ensino de morfossintaxe do português. Logo, os referidos artigos constituem um material que muito pode contribuir para a formação dos docentes de Língua Portuguesa - objetivo principal do Programa de Mestrado Profissional em Letras (PROFLETRAS), a que a Pensares em Revista está relacionada.

O primeiro artigo aborda a confusão na demarcação de pontos investigativos no âmbito dos estudos de morfossintaxe. Por isso, Marcelo Moraes Caetano procura estabelecer dois planos distintos: o plano do léxico e o plano da gramática, os quais têm relação direta com a dicotomia saussuriana sintagma e paradigma, como critério fundamental para elucidar a questão daquela demarcação.

No segundo artigo, José Mario Botelho retoma a antiga discussão acerca da formação de feminino dos substantivos portugueses e, sob a perspectiva da imanência do gênero dessa classe de palavra, assevera que não se trata de flexão o referido processo e apresenta uma proposta didática para o ensino da formação de feminino opositivo a uma base masculina, a que a Tradição postula como uma flexão de gênero.

No terceiro, Liliane Alves Santana Malacoski, Keila Mara Schneider e Aucione das Dores Smarsaro, tomando como escopo o verbo "perder", apresentam uma discussão sobre a importância dos estudos descritivos dos verbos para o ensino de língua portuguesa. As autoras constataram que "perder" é muito produtivo como verbo suporte e como componente de expressões fixas.

No quarto artigo, Vinicius Maciel de Oliveira e Gisele Aparecida Toledo Esteves discutem o ensino de perífrases verbais e verbo-nominais, tendo como base a análise de gramáticas tradicionais e descritivas, para destacar a proposta de que os usos moldam o sistema linguístico, como defende a perspectiva funcionalista adotada pelos autores como fundamentação teórica. .

O quinto artigo propõe uma reflexão sobre o ensino de morfossintaxe do português do Brasil. Nele, Rosângela Gomes Ferreira Divino e José Augusto Oliveira Pires focalizam os processos de formação de palavras sob a perspectiva sociocognitiva, a qual abrange todos os sistemas linguísticos simultaneamente.

No sexto artigo, José Pereira da Silva enfatiza a carência de produções lexicográficas relativas à terminologia linguística e gramatical em português e anuncia a chegada do seu Dicionário linguístico-gramatical da língua portuguesa, como um elemento compensador da referida carência de produções. O material, que aqui nos é oferecido pelo autor, reflete sobre os vários enfoques possíveis em definições dos termos linguísticos e gramaticais em destaque.

No sétimo e último artigo, Valéria Cavalcanti Muniz discorre sobre a plurifuncionalidade dos sinais de pontuação na construção de sentidos dos textos, refletindo sobre as dimensões prosódica, sintática, discursiva e semântica do emprego do sistema pontuatório. 
Em seguida, José Mario Botelho apresenta uma resenha da obra do Professor Doutor Claudio Cezar Henriques, intitulada Morfologia: Estudos lexicais em perspectiva sincrônica". Como ressalta o autor da referida resenha, o texto é propriamente um resumo da obra em destaque, em que se procurou apresentar ao amigo leitor os pontos de morfologia portuguesa abordados na obra sem que se fizesse comentários críticos ou juízo de valor.

Por fim, o próprio editor deste nono volume da pensares em Revista - José Mario Botelho (sob o epíteto JMB) - entrevista o Professor Doutor Claudio Cezar Henriques. As seis perguntas desta breve entrevista giram em torno da Morfologia, mormente acerca dos aspectos morfossintáticos que direta ou indiretamente incidem sobre a transmissão de conhecimento morfológico a estudantes e estudiosos do assunto.

Assim, podemos dizer que os presentes textos constituem um material produtivo para a formação daqueles que têm o mister de abordar e ensinar os conhecimentos morfológicos da língua portuguesa. Logo o conteúdo deste volume da Pensares em Revista, certamente, contribuirá para a prática docente, no âmbito dos processos de formação docente continuada, a que o PROFLETRAS da Faculdade de Formação de Professores da UERJ está ligado.

Portanto, esperamos ter atingido o objetivo almejado e lhes desejamos uma ótima leitura.

Prof. Dr. José Mario Botelho

Editor 